\title{
Restricted leptin antagonism as a therapeutic approach to treatment of autoimmune diseases
}

\author{
Arash Babaei ${ }^{1,2}$, Sayyed Hamid Zarkesh-Esfahani ${ }^{1}$, Ehsan Bahrami ${ }^{1}$, Richard J. Ross ${ }^{3}$ \\ ${ }^{1}$ Department of Biology, Faculty of Sciences, University of Isfahan, Isfahan, and ${ }^{2}$ University of Malayer, Malayer, Iran, \\ ${ }^{3}$ Academic Unit of Diabetes, Endocrinology and Reproduction, University of Sheffield, Sheffield, UK
}

\begin{abstract}
Leptin, the adipocyte derived hormone, has a pivotal role in regulating energy homeostasis and appetite. Beyond this essential role in bodyweight control, leptin also regulates the immune responses. Leptin has pro-inflammatory effects on $T$ cell populations, shifting the $T$ helper balance towards a TH1 phenotype, through induction of pro-inflammatory cytokines and stimulation of macrophage and natural killer cell function. Acute starvation reduces serum leptin levels, resulting in an impaired cellular immune response. The TH1 pro-inflammatory immune response, a homeostatic response mediated by the low leptin levels, is also impaired during starvation. Leptin-deficient or leptin receptor mutant mice are protected against the development of several inflammatory or various $T$ cell-dependent autoimmune diseases. Therefore, leptin appears to have a central role in the immune response and low leptin levels may protect against autoimmune disease. Here we review the role of leptin in the immune responses, with emphasis on autoimmune diseases. We will also discuss the application of leptin antagonist therapy for prevention and treatment of immunity related disorders.
\end{abstract}

Key words: Adipocyte hormone, Antagonism, Autoimmune disease, Immune response, Leptin

\section{INTRODUCTION}

The $o b / o b$, or obese, mouse is a mutant mouse suffering from a complex syndrome primarily characterised by excessive appetite; it becomes profoundly obese and suffers endocrinological disorders. In 1994, Jeffrey Friedman and colleagues found that leptin

Address for correspondence:

S.H. Zarkesh-Esfahani, Department of Biology, Faculty of

Sciences, University of Isfahan, Hezar Jerib Street, Isfahan,

Postcode: 81746-73441, I.R. Iran,

Tel: +98(311)7932473, Fax: +98(311)7932456,

E-mail address: s.h.zarkesh@sheffield.ac.uk

Received 11-07-10, Revised 20-10-10, Accepted 12-11-10 was the product encoded by the $o b$ gene. ${ }^{1}$ Leptin is a $16 \mathrm{kDa}$ nonglycosylated protein hormone consisting of 167 aminoacids. The elucidation of its structure revealed that leptin is an $\alpha$-helical-bundle cytokine. ${ }^{2}$ Leptin consists of four interconnected anti-parallel $\alpha$-helices and has a high similarity to other members of this large cytokine family, including growth hormone, interleukins such as interleukin-6 (IL-6), IL-11, IL-12, granulocytes colony stimulating factor (G-CSF), leukaemia inhibitory factor (LIF) and oncostatin M (OSM). ${ }^{3,4}$

Leptin is predominantly produced by adipocytes and its circulating level positively correlates with white 
adipose tissue mass. Administration of leptin to $o b /$ $o b$ mice increases basal metabolism and reduces food intake, leading to a remarkably rapid weight loss. ${ }^{5-7}$ Leptin interacts with the leptin receptor, also known as LepR or Ob-R, which is encoded by the $d b$ gene in humans and has a single transmembrane-spanning domain. Ob-R has also been designated as cluster of differentiation $295\left(\mathrm{CD}_{295}\right)^{8}$ and belongs to the class I cytokine receptor super family. ${ }^{9}$

There are six isoforms of the leptin receptor (Ob$\mathrm{Ra}-\mathrm{f})$ : one long (Ob-Rb), four short (Ob-Ra, c, d and $\mathrm{f}$ ) and one secreted (Ob-Re), ${ }^{10,11}$ resulting from alternative mRNA splicing; they differ in the length of their intracellular tails but share identical extracellularbinding domains. Leptin circulates both as a biologically active free form and a presumably inactive, bound form associated with plasma proteins and the soluble leptin receptor isoform $\mathrm{Ob}-\mathrm{Re} .{ }^{12} \mathrm{Ob}-\mathrm{Rb}$ is present in a number of hypothalamic nuclei. Leptin binds to the ventromedial nucleus of the hypothalamus, known as the "appetite center". ${ }^{13} d b / d b$ mice have a deletion in the long isoform of the leptin receptor and are resistant to leptin. ${ }^{14}$ The long isoform $\mathrm{Ob}-\mathrm{Rb}$ has a predicted 306 amino acids intracellular domain in man and is responsible for most of the known effects of leptin through its complete intracellular tail, at which the signalling of four different pathways involving Janus kinase and signal transducer and activator of transcription (JAK-STAT), mitogen-activated protein kinase (MAPK), phosphatidyl inositol 3 kinase $\left(\mathrm{PI}_{3} \mathrm{~K}\right)$ and adenosine-monophosphate activated kinase (AMPK) can occur. ${ }^{11}$ The short form (Ob-Ra) is much more widely expressed, often at higher levels, compared to the long form, e.g. in the choroid plexus, kidney, cells of the immune system, lung and liver. ${ }^{4}$ The short isoforms might be involved in leptin transport through the blood-brain barrier (BBB) and in other unknown functions.

Interestingly, $\mathrm{Ob}-\mathrm{Rb}$ is also expressed by endothelial cells, pancreatic $\beta$-cells, the ovary, $\mathrm{CD}_{34}{ }^{+}$ haematopoietic bone marrow precursors, monocytes/ macrophages, and $\mathrm{T}$ and $\mathrm{B}$ cells., ${ }^{415-21}$ Although an important role of leptin is to regulate bodyweight through the inhibition of food intake and stimulation of energy expenditure by increased thermogenesis, recent evidence has indicated that leptin is much more than a "fat-o-stat" sensor, ${ }^{22}$ as suggested by the pleiotropic nature characterising most $\alpha$-helical bundle cytokines. ${ }^{23}$

Leptin appears to be part of the complex network that coordinates immune responses to various stimuli. Its unique contribution may lie in integrating the body's energy status and thus adjusting the immune response to an appropriate energy level. Indeed, cellmediated immunity is an energy-demanding process, and impairment of this immunity during starvation may save energy necessary for vital body functions. Such crosstalk between energy homeostasis and the immune system appears to be bi-directional. ${ }^{24}$

\section{LEPTIN AND THE IMMUNE SYSTEM}

The pleiotropic role of leptin in mammalian physiology is clearly shown by the complex syndrome exhibited by leptin-deficient $o b / o b$ mice and leptin receptor-deficient $d b / d b$ mice. These mice are not only obese but also have abnormalities in reproductive function, hormone levels, wound repair, bone structure and immune function. ${ }^{18,25-29}$ Since administration of leptin in $o b / o b$ mice normalised the immune dysfunctions, a direct role of leptin in the regulation of the immune system has been suggested. ${ }^{26,30}$

$O b / o b$ and $d b / d b$ mice suffer from thymic atrophy and have reduced numbers of circulating lymphocytes. ${ }^{31-33}$ The impaired $\mathrm{T}$ cell immunity in these mice indicates a direct effect of leptin on $\mathrm{T}$ lymphocytes. This was substantiated by the demonstration of functional expression of $\mathrm{Ob}-\mathrm{Rb}$ on $\mathrm{CD}_{4}{ }^{+}$as well as on $\mathrm{CD}_{8}{ }^{+} \mathrm{T}$ cells. ${ }^{34,35}$ Leptin concentration lowered by starvation appears to correlate with impaired immune responses in mice. ${ }^{36}$ Although the risk of infection and death is highest when energy reserves are not sufficient, obesity, a state of energy excess, has also been associated with increased susceptibility to infections and poor wound healing. ${ }^{37}$ The effects of leptin on adaptive immune responses have been extensively investigated in human $\mathrm{CD}_{4}{ }^{+} \mathrm{T}$ cells. Leptin enhances proliferation of circulating blood $\mathrm{T}$ lymphocytes in a dose-dependent manner in in vitro conditions. ${ }^{34,35}$ Addition of leptin, in physiological concentrations, to a mixed lymphocytes reaction (MLR) induces a dose-dependent increase in $\mathrm{CD}_{4}{ }^{+} \mathrm{T}$ cell proliferation. ${ }^{34}$

Leptin appears to affect the T helper $(\mathrm{TH})$ balance leading to a shift towards the Thelper 1 (TH1) 
subset. Leptin stimulates TH1 production of proinflammatory cytokines: IL-2, interferon gamma (IFN- $\gamma$ ), tumour necrosis factor alpha (TNF- $\alpha$ ) and IL-18, with resultant decreased production of the TH2 cytokines: IL-4, IL-5 and IL-10 ${ }^{34,35}$ (Figure 1). T lymphocytes from $d b / d b$ mice do not demonstrate such responses, supporting the concept that this effect directly involves the leptin receptor expressed on the T lymphocytes. It was shown that leptin inhibits anti$\mathrm{CD}_{3}$ driven proliferation of memory $\mathrm{T}$ cells, while that of naive $\mathrm{T}$ cells was significantly enhanced.$^{38}$ Leptin increases the expression of adhesion molecules, such as intercellular adhesion molecule 1 (ICAM1, $\mathrm{CD}_{54}$ ) and very late antigen $2\left(\mathrm{VLA} 2, \mathrm{CD}_{49} \mathrm{~B}\right)$, by $\mathrm{CD}_{4}{ }^{+} \mathrm{T}$ cells, possibly through the induction of pro-inflammatory cytokines such as IFN- $\gamma .{ }^{39}$

Leptin also seems to be a regulator of natural killer (NK) cell development and activation. $D b / d b$ mice show decreased numbers of NK cells in the liver, spleen, lung and peripheral blood. In normal mice leptin administration increases the basal or induced lysis of splenocytes, but not in $d b / d b$ mice. ${ }^{40} \mathrm{Ob} / \mathrm{ob}$ mice are protected from $\mathrm{T}$ cell mediated hepatotoxicity. This effect obviously depends on the leptin-mediated

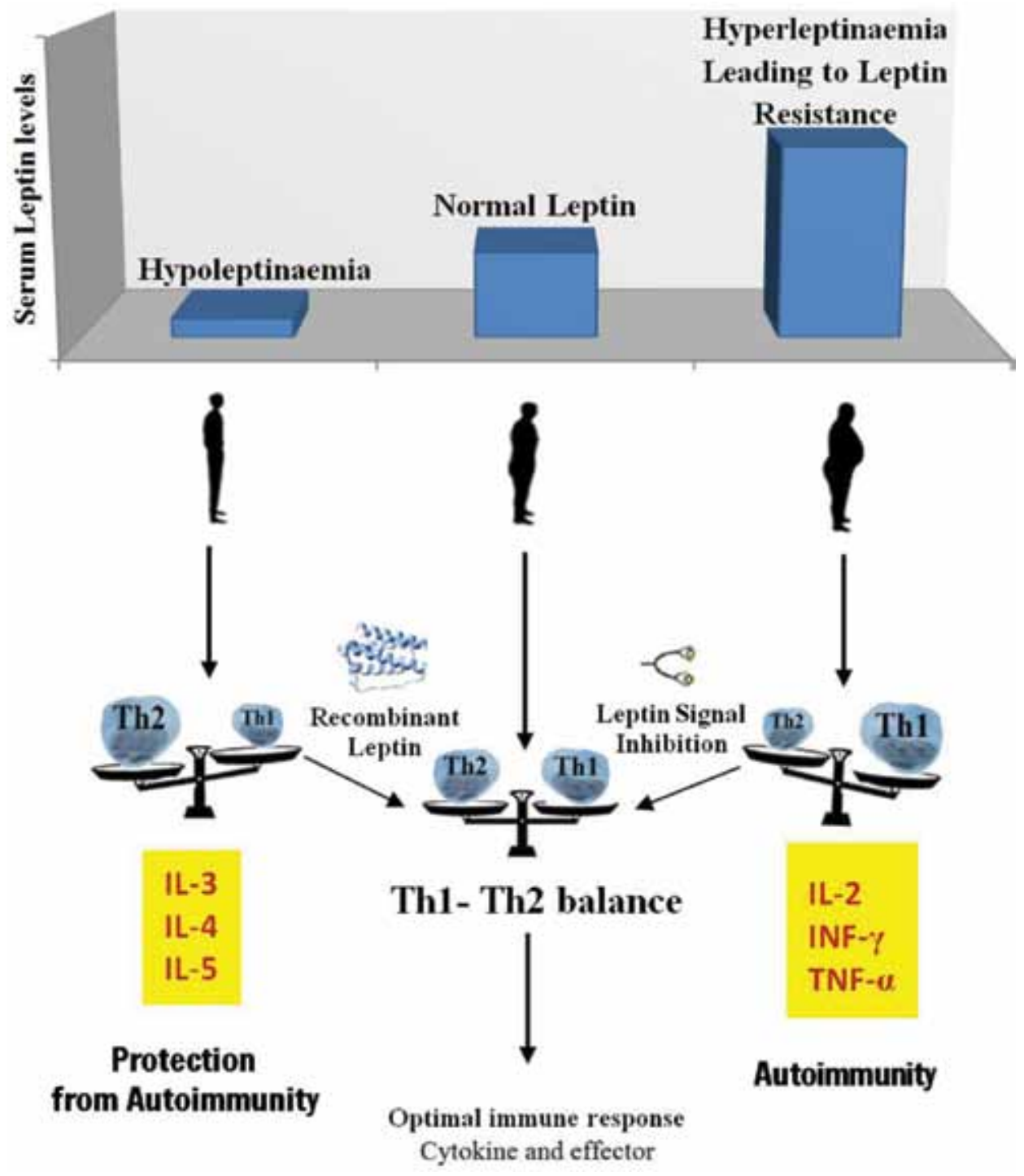

Figure 1. Relationship between Th1-Th2 balancing, autoimmune diseases and leptin. High leptin levels tend to shift toward Th1 and susceptibility to autoimmune disease, which could be reversed by leptin signal inhibition. Reduced leptin levels leads to susceptibility to infection and probably protection against autoimmune diseases. 
production of the pro-inflammatory IL-18 and TNF- $\alpha$ cytokines. ${ }^{31}$

\section{LEPTIN AND THE INFLAMMATORY RESPONSE}

Leptin is one of the mediators commonly present in the neuroendocrine and immune systems. ${ }^{1}$ In the immune system, leptin, together with C-reactive protein (CRP), IL-1 and IL-6, can act as an early acute-phase reactant, produced at high levels during inflammation, sepsis and fever, and it can also be induced by other inflammatory mediators such as TNF- $\alpha$ and IL-1 ${ }^{15,41,42}$ Peritoneal macrophages from $o b / o b$ mice display a lower phagocytic activity as compared to macrophages of normal mice. Administration of leptin restored this phagocytosis deficiency. ${ }^{43}$ Furthermore, the production of granulocyte macrophage colony stimulating factor (GM-CSF), G-CSF ${ }^{44}$ and the proinflammatory cytokines TNF- $\alpha$, IL- 6 and IL- $12^{43}$ by murine macrophages are enhanced after treatment with leptin. This study has demonstrated that leptin induces production of TNF- $\alpha$, IL- 6 and IFN- $\gamma$ from resting human peripheral blood mononuclear cells (PBMCs) and enhances release of these cytokines from stimulated PBMCs. ${ }^{45}$ It has also been shown that, at least in human neutrophils, leptin seems to mediate its effects through an indirect mechanism, probably involving the release of TNF- $\alpha$ from monocytes. ${ }^{46}$ Leptin also stimulates the secretion of the IFN- $\gamma$ inducible protein in human monocytic cells, as well as in PBMCs. ${ }^{47}$ This protein acts as a chemo-attractant for lymphocytes and monocytes ${ }^{48}$ recruiting activated T cells to the site of inflammation. ${ }^{48,49}$

All patients in a clinical trial, using recombinant leptin for weight loss, showed signs of inflammatory reaction at the site of recombinant leptin injection. ${ }^{50}$

\section{LEPTIN AND AUTOIMMUNE DISEASES}

Considering that congenital deficiency of leptin is associated with increased frequency of infection and related mortality, ${ }^{51}$ it was hypothesized that a low concentration of serum leptin might contribute to increased susceptibility to infection by reducing $\mathrm{T}$ helper cell priming and by affecting thymic function. ${ }^{26,34}$ On the other hand, the TH1 promoting effects of leptin have clearly been linked with an enhanced susceptibility for experimentally induced autoim- mune disease including experimental autoimmune encephalomyelitis (EAE), type 1 diabetes (T1D) and antigen-induced arthritis (AIA). ${ }^{52}$

Leptin, as shown by evidence presented in the previous section, plays an important role in $\mathrm{CD}_{4}{ }^{+} \mathrm{T}$ cell mediated immune responses, promoting a proinflammatory TH1 response. Evidence is accumulating that leptin also plays a determining role in the development of $\mathrm{CD}_{4}{ }^{+} \mathrm{T}$ cell mediated autoimmune diseases including Crohn's disease, rheumatoid arthritis (RA), multiple sclerosis (MS) and T1D. This concept has been the subject of many researches, some of which are summarized in Tables 1A and 1B.

In experimental mouse model systems for human inflammatory bowel disease (Crohn's disease with acute and chronic colitis), leptin-deficient $o b / o b$ mice showed a $72 \%$ reduction of colitis severity and a marked decrease of pro-inflammatory cytokines (IFN- $\gamma$, TNF- $\alpha$, IL-1 $\beta$, IL-18 and IL-6) in colon cell culture supernatants, compared to wild-type mice. Administration of leptin in $o b / o b$ mice eliminates this resistance against experimentally induced colitis. ${ }^{53} \mathrm{In}$ another study on a murine model of inflammatory bowel disease, Clostridium difficile toxin A caused severe colitis but $o b / o b$ as well as $d b / d b$ mice were partially protected from toxin A-induced intestinal secretion and inflammation. Leptin administration in $o b / o b$, but not in $d b / d b$ mice, eliminated this protection..$^{54}$

Other data strongly indicate that leptin may be required for development of EAE, and possibly for multiple sclerosis in humans. Genetically leptindeficient mice are resistant to induction of both active and adoptively transferred EAE. This protection is reversed by leptin administration and is associated with a switch from TH2 to TH1 type responses and $\mathrm{IgG1}$ to IgG2a isotype switch. Similarly, in susceptible wild-type C57BL/6J mice, leptin worsens EAE disease by increasing IFN- $\gamma$ release and $\mathrm{IgG} 2$ a production. ${ }^{55}$ Serum leptin levels are significantly higher in MS patients compared to sex and age matched healthy volunteers (personal unpublished data). It has also been shown that serum leptin levels in 41 women with systemic lupus erythematosus were significantly higher than in an age, sex and body mass index matched control group. ${ }^{56}$ 
Table 1A. Selected papers investigating the relationship between leptin (L) and the immune system demonstrating the influence of $\mathrm{L}$ on induction, maintenance and clinical manifestations of some autoimmune conditions

\begin{tabular}{|c|c|c|c|c|c|}
\hline Year & $\begin{array}{l}\text { Country/ } \\
\text { Ref. number }\end{array}$ & Main findings & Type of study & Disease/Condition & $\begin{array}{l}\text { Leptin effect on } \\
\text { the immune system }\end{array}$ \\
\hline 2007 & $\mathrm{UK}^{75}$ & $\begin{array}{l}\text { Plasma L was positively correlated } \\
\text { with metabolic, inflammatory and } \\
\text { risk factors for CVD }\end{array}$ & $\begin{array}{l}3640 \text { men aged } \\
60-79 \text { years }\end{array}$ & CVD & L causes inflammation \\
\hline 2006 & Israel $^{76}$ & $\begin{array}{l}\text { L induces significant suppression } \\
\text { of human hepatocellular } \\
\text { carcinoma }\end{array}$ & $\begin{array}{l}\text { Athymic nude } \\
\text { mice }\end{array}$ & & $\begin{array}{l}\text { L enhances natural killer } \\
\text { cells activity }\end{array}$ \\
\hline 2007 & Italy $^{77}$ & $\begin{array}{l}\mathrm{L} \text { acts as a negative signal for the } \\
\text { proliferation of human, naturally } \\
\text { occurring Foxp } 3^{+} \mathrm{CD} 4^{+} \mathrm{CD} 25^{+} \\
\text {regulatory } \mathrm{T}\left(\mathrm{T}_{\mathrm{reg}}\right) \text { cells }\end{array}$ & $\begin{array}{l}\text { Human } \mathrm{T}_{\mathrm{reg}} \\
\text { cells }\end{array}$ & $\begin{array}{l}\text { Autoimmune } \\
\text { diseases }\end{array}$ & $\begin{array}{l}\text { L can modulate the } \\
\text { hyporesponsiveness and } \\
\text { proliferation of } \mathrm{T}_{\text {reg }} \text { cells } \\
\text { both in vitro and in vivo }\end{array}$ \\
\hline 2005 & Brazil $^{78}$ & $\begin{array}{l}\text { L may be involved in some } \\
\text { of the cellular defects } \\
\text { observed in common variable } \\
\text { immunodeficiency }\end{array}$ & 38 patients & $\begin{array}{l}\text { Common variable } \\
\text { immunodeficiency }\end{array}$ & $\begin{array}{l}\text { L causes proliferative } \\
\text { response of lymphocytes, } \\
\text { IL-2 and IL-4 production }\end{array}$ \\
\hline 2006 & $\begin{array}{l}\text { Czech } \\
\text { Republic }^{79}\end{array}$ & $\begin{array}{l}\text { Corticosterone does not } \\
\text { stimulate leptin production } \\
\text { during AA }\end{array}$ & Rats & $\begin{array}{l}\text { AA an experimental } \\
\text { model of human RA }\end{array}$ & $\begin{array}{l}\text { The suppression of } \mathrm{L} \\
\text { may be a consequence of } \\
\text { permanent activation of } \\
\text { NO and IL-1 } \beta \text {. }\end{array}$ \\
\hline 2009 & $\mathrm{USA}^{80}$ & $\begin{array}{l}\text { L induces CRP expression } \\
\text { in human coronary artery } \\
\text { endothelial cells via activation } \\
\text { of the leptin receptor }\end{array}$ & $\begin{array}{l}\text { Human } \\
\text { coronary artery } \\
\text { endothelial cells }\end{array}$ & $\begin{array}{l}\text { Pro-atherogenic } \\
\text { effects of } \mathrm{L}\end{array}$ & $\begin{array}{l}\text { Induction of CRP } \\
\text { expression }\end{array}$ \\
\hline 2010 & Canada $^{81}$ & $\begin{array}{l}\text { Action of } \mathrm{L} \text { on microglia is that } \\
\text { of a modulator rather than a } \\
\text { direct trigger of inflammation }\end{array}$ & $\begin{array}{l}\text { Microglia } \\
\text { cultures } \\
\text { prepared from } \\
\text { rat brain }\end{array}$ & $\begin{array}{l}\text { Microglial function } \\
\text { in inflammation }\end{array}$ & $\begin{array}{l}\text { L induces production } \\
\text { of IL- } 1 \beta \text {, TNF- } \alpha \text { and } \\
\text { chemokines such as } \\
\text { CINC- } 1 \text { and MIP-2 }\end{array}$ \\
\hline 2009 & $\begin{array}{l}\text { South } \\
\text { Korea }^{82}\end{array}$ & $\begin{array}{l}\text { L, IL- } 6 \text { and TNF- } \alpha \text { mRNA } \\
\text { expression of PMBCs from } \\
\text { patients with AS were } \\
\text { significantly higher than controls }\end{array}$ & $\begin{array}{l}\text { Twenty patients } \\
\text { with active AS } \\
\text { and } 20 \text { healthy } \\
\text { controls }\end{array}$ & AS & $\begin{array}{l}\text { Higher L, IL- } 6 \text {, and } \\
\text { TNF- } \alpha \text { mRNA } \\
\text { expressions in patients } \\
\text { with AS }\end{array}$ \\
\hline
\end{tabular}

PBMCs: peripheral blood mononuclear cells, ITP: idiopathic thrombocytopenic purpura, CVD: cardiovascular disease, AA: adjuvant arthritis, AS: ankylosing spondylitis, RA: rheumatoid arthritis, MS: multiple sclerosis, CRP: C reactive protein.

Chronic idiopathic thrombocytopenic purpura (ITP) is an organ-specific autoimmune disease characterized by the production of antibodies against antigens on the membranes of platelets, resulting in enhanced destruction of the platelets by macrophages. Leptin enhances in vitro secretion of IgG anti-platelet antibodies by splenocytes and PBMCs from patients with chronic ITP. After depletion of $\mathrm{CD}_{4}{ }^{+} \mathrm{T}$ cells from splenocytes, leptin loses this function. Further studies showed that leptin could increase platelet reactive $\mathrm{T}$ cells. These findings suggest that leptin may be involved in the pathogenesis of chronic ITP and thus might offer a potential target for the treatment of this disease. ${ }^{57}$

There are data suggesting a role for leptin in the development of RA. Injection of methylated bovine serum albumin (BSA) in the knees of mice results in the development of AIA. In contrast, $o b / o b$ and $d b /$ $d b$ mice develop less severe arthritis as compared to wild-type mice and have decreased IL- $1 \beta$ and TNF- $\alpha$ in the knee synovial fluid and decreased serum levels of anti-methylated BSA antibodies. Furthermore, decreased antigen-specific $\mathrm{T}$ cell proliferative response, 
Table 1B. Selected papers investigating the relationship between leptin (L) and the immune system demonstrating the influence of L on induction, maintenance and clinical manifestations of some autoimmune conditions

\begin{tabular}{|c|c|c|c|c|c|}
\hline Year & $\begin{array}{l}\text { Country/ } \\
\text { Ref. number }\end{array}$ & Main findings & Type of study & Disease/Condition & $\begin{array}{l}\text { L effect on the immune } \\
\text { system }\end{array}$ \\
\hline 2005 & Italy & $\begin{array}{l}\text { Involvement of } \mathrm{L} \text { and IL- } 6 \text { in } \\
\text { the action of interferon-beta in } \\
\text { secondary, progressive MS }\end{array}$ & $\begin{array}{l}18 \text { secondary } \\
\text { progressive MS } \\
\text { patients }\end{array}$ & MS & $\begin{array}{l}\text { The effect of IFN- } \beta \\
\text { on MS patients might } \\
\text { be associated with the } \\
\text { reduced levels of } L \text { and } \\
\text { reduced IL- } 6 \text { production } \\
\text { by PBMCs }\end{array}$ \\
\hline 2006 & China & $\begin{array}{l}\mathrm{L} \text { may be involved in the } \\
\text { pathogenesis of chronic ITP }\end{array}$ & $\begin{array}{l}\text { PBMCs from } \\
18 \text { chronic ITP } \\
\text { patients and } 14 \\
\text { controls }\end{array}$ & Chronic ITP & $\begin{array}{l}\text { Ln enhances production } \\
\text { of anti-platelet antibodies }\end{array}$ \\
\hline 2008 & Poland $^{84}$ & $\begin{array}{l}\text { Increased L levels in peritoneal } \\
\text { fluid from endometriosis patients } \\
\text { may affect local inflammatory/ } \\
\text { immune reactions, especially } \\
\text { infiltration of CD4+ T helper } \\
\text { cells. }\end{array}$ & $\begin{array}{l}\text { Peritoneal fluid } \\
\text { of } 46 \text { patients } \\
\text { and } 10 \text { control } \\
\text { women }\end{array}$ & Endometriosis & $\begin{array}{l}\text { L correlates with } \\
\text { inflammatory cytokines } \\
\text { (IL-1 } \beta \text {, IL-6, IFN- } \gamma \text { and } \\
\text { TNF- } \alpha \text { ) }\end{array}$ \\
\hline 2007 & Italy ${ }^{85}$ & $\begin{array}{l}\text { ObR may be involved in the } \\
\text { development of clinical relapses in } \\
\text { RRMS patients }\end{array}$ & $\begin{array}{l}\text { CD8+ T cells } \\
\text { and monocytes } \\
\text { from RRMS } \\
\text { patients }\end{array}$ & RRMS & $\begin{array}{l}\text { L-induced IL- } 6 \\
\text { production can be } \\
\text { modulated by SOCS3 } \\
\text { expression }\end{array}$ \\
\hline 2001 & $\mathrm{UK}^{45}$ & $\begin{array}{l}\mathrm{L} \text { has a direct effect on the } \\
\text { generation of an inflammatory } \\
\text { response. }\end{array}$ & Human PBMCs & $\begin{array}{l}\text { s Endotoxin stimulated } \\
\text { and resting human } \\
\text { PBMCs }\end{array}$ & $\begin{array}{l}\text { L induces production of } \\
\text { TNF- } \alpha \text {, IL- } 6 \text { and IFN- } \gamma\end{array}$ \\
\hline
\end{tabular}

PBMCs: peripheral blood mononuclear cells, ITP: idiopathic thrombocytopenic purpura, CVD: cardiovascular disease, AA: adjuvant arthritis, AS: ankylosing spondylitis, RA: rheumatoid arthritis, MS: multiple sclerosis, CRP: C reactive protein, RRMS: remitting relapsing multiple sclerosis.

with a lower IFN- $\gamma$ and a higher IL-10 secretion, typical for a shift towards an anti-inflammatory $\mathrm{TH} 2$ type phenotype, has also been reported. ${ }^{58}$ Reducing leptin levels in RA patients by fasting ameliorates the clinical signs of the disease. ${ }^{39}$ Leptin antagonism has therefore been suggested for prevention of developing RA in people who are genetically susceptible to RA and other autoimmune diseases.

In the non-obese diabetic (NOD) mouse, an animal model for type 1 diabetes (an autoimmune disease in which the pancreatic $\beta$-cells are destroyed by inflammatory processes), an increased serum level of leptin precedes diabetes in susceptible females, while injection of leptin accelerates the autoimmune destruction of the pancreatic $\beta$-cells and increases the IFN- $\gamma$ production in peripheral T cells. These effects indicate that leptin promotes the development of type 1 diabetes through $\mathrm{TH} 1$ responses. ${ }^{59}$
In MS and RA, 60 to $75 \%$ of the patients are female, and in other autoimmune diseases (thyroiditis, scleroderma, lupus erythematosus, Sjögren's disease), $85 \%$ or more of the patients are female. This is corroborant that autoimmune diseases affect women more than men. ${ }^{60}$ This gender effect may, at least in part, reflect the higher average leptin concentrations in women. ${ }^{61}$

Autoimmune diseases show an increasing incidence in industrialised countries compared to less developed countries. Some researchers now believe that leptin helps to determine the balance between predisposition to infections and predisposition to autoimmune diseases. This could help explain why higher circulating leptin levels predispose to autoimmune diseases and lower circulating leptin levels to infection. ${ }^{22}$ Based on the evidence regarding relationship between leptin and autoimmune diseases, leptin antagonism has been 
proposed as an immunotherapeutic approach for the treatment of some autoimmune disorders and even in a wider range as an effective immunosuppresant. ${ }^{62}$

\section{LEPTIN SIGNAL INHIBITION STRATEGIES}

There are different approaches for designing antagonists. Blocking common important signal pathways, such as JAK-STAT, may result in detrimental effects. So far there is no commercially available leptin antagonist that can be used for clinical studies. The recent development of leptin mutants with antagonistic properties and other proteins that block leptin activity opens up new possibilities for their use in research and, eventually, therapy. ${ }^{63}$

Using site-directed mutagenesis for single amino acid residues in human leptin, which are critical for receptor binding and biological activity, has resulted in mutants with antagonistic properties that are able to interfere with the negative feedback control of endogenous leptin. ${ }^{64}$ Binding site II in the leptin molecule is composed of residues at the surface of helices A and C. Mutations in this site impair binding to $\mathrm{CRH} 2$ in the leptin receptor but have only a limited effect on signalling. Some leptin mutants behave as potent leptin antagonists both in vitro and in vivo. ${ }^{65}$ Mutations in binding site III of leptin interfere with the hexamerisation process and thus with receptor activation. A S120A/T121A binding site III leptin mutant still binds to the receptor but is unable to activate the receptor. It therefore acts as a competitive inhibitor of leptin receptor signalling. ${ }^{65}$ Given the very short half-life of leptin in circulation (minutes), blocking effects of a leptin antagonist in vivo can only be observed when its half-life is extended (hours). To increase the circulation lifetime of the S120A/T121A leptin antagonist, PEGylation of this mutant has been suggested. ${ }^{66}$

Local delivery of leptin antagonists offers an alternative possibility. Several autoimmune diseases are limited to a specific tissue, for example, Crohn's disease to the intestine. In this particular case, local delivery of a leptin antagonist can be envisaged using a Lactococcus or Lactobacillus delivery system, as has been demonstrated using recombinant IL-10 secreting Lactococcus lactis. ${ }^{67,68}$

One of the most extensively studied and applied approaches, when it comes to antagonising cytokines, is the design of neutralizing antibodies, since they combine high binding affinity and specificity. The development of various antibodies against leptin or leptin receptor mutants with antagonistic properties may hold promise as a therapeutic option for autoimmune and/or other disorders. ${ }^{69}$ A number of studies have described the use of anti-leptin or anti-leptin receptor antibodies for detection and quantification purposes. ${ }^{70-73}$ A monoclonal antibody against human leptin receptor with antagonistic effect has been described. In vitro studies demonstrated that this $\mathrm{mAb}$ is able to inhibit leptin-induced TNF- $\alpha$ production from human monocytes and anti- $\mathrm{CD}_{3} \mathrm{mAb}$ induced proliferation of human T cells in PBMC culture. ${ }^{74}$

A critical issue concerning leptin is its pleiotropic nature, as discussed earlier. Any attempt to block the leptin signalling in vivo should be carefully planned as it may cause undesirable effects. The biggest advantage of recombinant antibody ( $\mathrm{rAb}$ ) technology is that $\mathrm{rAb}$ can be subjected to genetic manipulation (e.g. humanization, conjugation with other molecules, etc.) and more importantly can produce molecules with affinity for different epitopes which bind simultaneously to at least two different molecules. Therefore, they can block a specific molecule (such as the leptin receptor) on a specific target tissue, leaving other actions of the leptin receptor unaffected.

\section{CONCLUDING REMARKS}

The hypothalamic leptin/leptin receptor system is a determining component of the control of energy homeostasis and bodyweight. Leptin has also emerged as a pleiotropic cytokine with important effects in several peripheral tissues. However, as early leptin research has primarily been focussed on the effect of leptin on bodyweight regulation, little attention has been given to the development of leptin antagonists specifically designed for peripheral effects. Adequate nutrition is a prerequisite for generating appropriate immune responses against pathogens. Accordingly, sufficient energy stores may be one of the factors required for long-term, detrimental immune reactions, as observed in autoimmune diseases. Serum leptin is important for $\mathrm{T}$ cell proliferation and there is an autocrine loop of leptin to maintain T cell proliferation..$^{86,87}$ 
The link between leptin and immune processes may therefore offer a new therapeutic strategy against autoimmune diseases. For this purpose there is a clear need for leptin antagonists. The monoclonal antibody against the human leptin receptor identified by our group and blocks leptin signalling, probably constitutes a promising tool for designing a tissue specific leptin antagonist. It has been shown that this antibody inhibits the pro-inflammatory activity of leptin by its ability to block peripheral immune actions of leptin and leptin-induced induction of TNF- $\alpha$ by human monocytes and $\mathrm{T}$ cell proliferation. ${ }^{74}$

Recent studies on the effects of leptin on the immune system suggests its decisive role in autoimmune processes. Tissue specific leptin antagonists may therefore have therapeutic value in different conditions related to the immune system including autoimmune disease, transplantation, selective immune suppression, etc.

\section{ACKNOWLEDGMENTS}

This study was conducted at the University of Isfahan and was supported by the Office of Graduate Studies. The authors are grateful to the Office for its support. The authors would like to thank Mr Michael Copeland and Malayer University for their help.

\section{REFERENCES}

1. Zhang Y, Proenca R, Maffei M, Barone M, Leopold L, Friedman JM, 1994 Positional cloning of the mouse obese gene and its human homologue. Nature 372: 425-432.

2. Zhang FM, Basinski MB, Beals JM, et al, 1997 Crystal structure of the obese protein leptin-E100. Nature 387: 206-209.

3. Baumann H, Morella KK, White DW, et al, 1996 The full-length leptin receptor has signaling capabilities of interleukin 6-type cytokine receptors. Proc Natl Acad Sci USA 93: 8374-8378.

4. Tartaglia LA, 1997 The leptin receptor. J Biol Chem 272: 6093-6096.

5. Halaas JL, Gajiwala KS, Maffei M, et al, 1995 Weightreducing effects of the plasma protein encoded by the obese gene. Science 269: 543-546.

6. Campfield LA, Smith FJ, Guisez Y, Devos R, Burn P, 1995 Recombinant mouse OB protein: evidence for a peripheral signal linking adiposity and central neural networks. Science 269: 546-549.

7. Pelleymounter MA, Cullen MJ, Baker MB, et al, 1995
Effects of the obese gene product on body weight regulation in ob/ob mice. Science 269: 540-543.

8. Laschober GT, Brunauer R, Jamnig A, Fehrer C, Greiderer B, Lepperdinger G, 2008 Leptin receptor/CD295 is upregulated on primary human mesenchymal stem cells of advancing biological age and distinctly marks the subpopulation of dying cells. Exp Gerontol 44: 57 62.

9. Chen H, Charlat O, Tartaglia LA, et al, 1996 Evidence that the diabetes gene encodes the leptin receptor: Identification of a mutation in the leptin receptor gene in $\mathrm{db} / \mathrm{db}$ mice. Cell 84: 491-495.

10. Mercer JG, Hoggard N, Williams LM, Lawrence CB, Hannah LT, Trayhurn P, 1996 Localization of leptin receptor mRNA and the long form splice variant (Ob$\mathrm{Rb}$ ) in mouse hypothalamus and adjacent brain regions by in situ hybridization. FEBS Lett 387: 113-116.

11. Hegyi K, Fulop K, Kovacs K, Toth S, Falus A, 2004 Leptin-induced signal transduction pathways. Cell Biol Int 28: 159-169.

12. Sinha MK, Opentanova I, Ohannesian JP, et al, 1996 Evidence of free and bound leptin in human circulation. Studies in lean and obese subjects and during short-term fasting. J Clin Invest 98: 1277-1282.

13. Saladin R, Devos P, Guerremillo M, et al, 1995 Transient increase in obese gene-expression after food-intake or insulin administration. Nature 377: 527-529.

14. Lee GH, Proenca R, Montez JM, et al, 1996 Abnormal splicing of the leptin receptor in diabetic mice. Nature 379: 632-635.

15. Friedman JM, Halaas JL, 1998 Leptin and the regulation of body weight in mammals. Nature 395: 763-770.

16. Park JH, Lee HH, Na SY, et al, 2001 Recombinant expression of biologically active rat leptin in Escherichia coli. Protein Expr Purif 22: 60-69.

17. Sierra-Honigmann MR, Nath AK, Murakami C, et al, 1998 Biological action of leptin as an angiogenic factor. Science 281: 1683-1686.

18. Ducy P, Amling M, Takeda S, et al, 2000 Leptin Inhibits Bone Formation through a Hypothalamic Relay A Central Control of Bone Mass. Cell 100: 197-207.

19. Lord GM, Matarese G, Howard JK, Baker RJ, Bloom SR, Lechler RI, 1998 Leptin modulates the T-cell immune response and reverses starvation-induced immunosuppression. Nature 394: 897-901.

20. Sanchez-Margalet V, Martin-Romero C, Santos-Alvarez J, Goberna R, Najib S, Gonzalez-Yanes C, 2003 Role of leptin as an immunomodulator of blood mononuclear cells: mechanisms of action. Clin Exp Immunol 133: 11-19.

21. Tartaglia LA, Dembski M, Weng X, et al, 1995 Identification and expression cloning of a leptin receptor, OB-R. Cell 83: 1263-1271.

22. Matarese G, La Cava A, Sanna V, et al, 2002 Balancing susceptibility to infection and autoimmunity: a role for leptin? Trends Immunol 23: 182-187. 
23. Ducy P, Amling M, Takeda S, et al, 2000 Leptin inhibits bone formation through a hypothalamic relay: A central control of bone mass. Cell 100: 197-207.

24. Peelman F, Iserentant H, Eyckerman S, Zabeau L, Tavernier J, 2005 Leptin, immune responses and autoimmune disease. Perspectives on the use of leptin antagonists. Curr Pharm Des 11: 539-548.

25. Chehab FF, Lim ME, Lu RH, 1996 Correction of the sterility defect in homozygous obese female mice by treatment with the human recombinant leptin. Nat Genet 12: 318-320.

26. Howard JK, Lord GM, Matarese G, et al, 1999 Leptin protects mice from starvation-induced lymphoid atrophy and increases thymic cellularity in ob/ob mice. J Clin Invest 104: 1051-1059.

27. Frank S, Stallmeyer B, Kampfer H, Kolb N, Pfeilschifter J, 2000 Leptin enhances wound re-epithelialization and constitutes a direct function of leptin in skin repair. J Clin Invest 106: 501-509.

28. Ring BD, Scully S, Davis CR, et al, 2000 Systemically and topically administered leptin both accelerate wound healing in diabetic ob/ob mice. Endocrinology 141: 446-449.

29. Fleet JC, 2000 Leptin and bone: Does the brain control bone biology? Nutr Rev 58: 209-211.

30. Faggioni R, Moser A, Feingold KR, Grunfeld C, 2000 Reduced leptin levels in starvation increase susceptibility to endotoxic shock. Am J Pathol 156: 1781-1787.

31. Faggioni R, Jones-Carson J, Reed DA, et al, 2000 Leptin-deficient (ob/ob) mice are protected from $\mathrm{T}$ cell-mediated hepatotoxicity: Role of tumor necrosis factor alpha and IL-18. Proc Natl Acad Sci USA 97: 2367-2372.

32. Mandel MA, Mahmoud AAF, 1978 Impairment of cellmediated immunity in mutation diabetic mice $(\mathrm{db} / \mathrm{db})$. J Immunol 120: 1375-1377.

33. Chandra RK, 1980 Cell-mediated immunity in genetically obese C57BL/6J ob/ob) mice. Am J Clin Nutr 33: 13-16.

34. Lord GM, Matarese G, Howard LK, Baker RJ, Bloom SR, Lechler RI, 1998 Leptin modulates the T-cell immune response and reverses starvation-induced immunosuppression. Nature 394: 897-901.

35. Martin-Romero C, Santos-Alvarez J, Goberna R, Sanchez-Margalet V, 2000 Human leptin enhances activation and proliferation of human circulating $\mathrm{T}$ lymphocytes. Cell Immunol 199: 15-24.

36. Ozata M, Ozdemir IC, Licinio J, 2000 Human leptin deficiency caused by a missense mutation: multiple endocrine defects, decreased sympathetic tone, and immune system dysfunction indicate new targets for leptin action, greater central than peripheral resistance to the effects of leptin, and spontaneous correction of leptin-mediated defects (vol 84, pg 3686, 1999). J Clinl Endocrinol Metab 85: 416-416.

37. Samartin S, Chandra RK, 2001 Obesity, overnutrition and the immune system. Nutrition Research 21: 243262.

38. Lord GM, Matarese G, Howard JK, Bloom SR, Lechler RI, 2002 Leptin inhibits the anti-CD3-driven proliferation of peripheral blood $\mathrm{T}$ cells but enhances the production of proinflammatory cytokines. J Leukoc Biol 72: 330338.

39. La Cava A, Matarese G, 2004 The weight of leptin in immunity. Nat Rev Immunol 4: 371-379.

40. Tian ZG, Sun R, Wei HM, Gao B, 2002 Impaired natural killer (NK) cell activity in leptin receptor deficient mice: leptin as a critical regulator in NK cell development and activation. Biochem Biophys Res Commun 298: 297-302.

41. Landman RE, Puder JJ, Xiao E, Freda PU, Ferin M, Wardlaw SL, 2003 Endotoxin stimulates leptin in the human and nonhuman primate. J Clin Endocrinol Metab 88: 1285-1291.

42. Orbak Z, Ertekin V, Akcay F, Ozkan B, Ors R, 2003 Serum leptin levels in neonatal bacterial septicemia. J Pediatr Endocrinol Metab16: 727-731.

43. Loffreda S, Yang SQ, Lin HZ, et al, 1998 Leptin regulates proinflammatory immune responses. Faseb Journal 12: 57-65.

44. Gainsford T, Willson TA, Metcalf D, et al, 1996 Leptin can induce proliferation, differentiation, and functional activation of hemopoietic cells. Proc Natl Acad Sci USA 93: 14564-14568.

45. Zarkesh-Esfahani H, Pockley G, Metcalfe RA, et al, 2001 High-dose leptin activates human leukocytes via receptor expression on monocytes. J Immunol 167: 4593-4599.

46. Zarkesh-Esfahani H, Pockley AG, Wu ZD, Hellewell PG, Weetman AP, Ross RJM, 2004 Leptin indirectly activates human neutrophils via induction of TNF-alpha. J Immunol 172: 1809-1814.

47. Meier CA, Chicheportiche R, Dreyer M, Dayer JM, 2003 IP-10, but not RANTES, is upregulated by leptin in monocytic cells. Cytokine 21: 43-47.

48. Taub DD, Lloyd AR, Conlon K, et al, 1993 Recombinant human interferon-inducible protein 10 is a chemoattractant for human monocytes and $\mathrm{T}$ lymphocytes and promotes $\mathrm{T}$ cell adhesion to endothelial cells. J Exp Med 177: 1809.

49. Mach F, Sauty A, Iarossi AS, et al, 1999 Differential expression of three $\mathrm{T}$ lymphocyte-activating CXC chemokines by human atheroma-associated cells. J Clin Invest 104: 1041-1050.

50. Heymsfield SB, Greenberg AS, Fujioka K, et al, 1999 Recombinant leptin for weight loss in obese and lean adults - A randomized, controlled, dose-escalation trial. JAMA 282: 1568-1575.

51. Ozata M, Ozdemir IC, Licinio J, 1999 Human leptin deficiency caused by a missense mutation: Multiple endocrine defects, decreased sympathetic tone, and immune system dysfunction indicate new targets for 
leptin action, greater central than peripheral resistance to the effects of leptin, and spontaneous correction of leptin-mediated defects. J Clin Endocrinol Metab 84: 3686-3695.

52. Ozata M, Uckaya G, Beyhan Z, Ozdemir IC, 1999 Plasma leptin levels in male patients with idiopathic central diabetes insipidus. Journal of Endocrinological Investigation 22: 451-454.

53. Siegmund B, Lehr HA, Fantuzzi G, 2002 Leptin: A pivotal mediator of intestinal inflammation in mice. Gastroenterology 122: 2011-2025.

54. Mykoniatis A, Anton PM, Wlk M, et al, 2003 Leptin mediates Clostridium difficile toxin A-induced enteritis in mice. Gastroenterology 124: 683-691.

55. Matarese G, Sanna V, Di Giacomo A, et al, 2001 Leptin potentiates experimental autoimmune encephalomyelitis in SJL female mice and confers susceptibility to males. Eur J Immunol 31: 1324-1332.

56. Garcia-Gonzalez A, Gonzalez-Lopez L, Valera-Gonzales IC, et al, 2002 Serum leptin levels in women with systemic lupus erythematosus. Rheumatol Int 22: 138-141.

57. Ren H, Zhao H, Wang TT, et al, 2006 Leptin enhances in vitro secretion of IgG antiplatelet antibodies by splenocytes and peripheral blood mononuclear cells from patients with chronic idiopathic thrombocytopenic purpura. Clin Immunol 120: 205-211.

58. Busso N, So A, Chobaz-Peclat V, et al, 2002 Leptin signaling deficiency impairs humoral and cellular immune responses and attenuates experimental arthritis. J Immunol 168: 875-882.

59. Matarese G, Sanna V, Lechler RI, et al, 2002 Leptin accelerates autoimmune diabetes in female NOD mice. Diabetes 51: 1356-1361.

60. Cooper GS, Stroehla BC, 2003 The epidemiology of autoimmune diseases. Autoimm Rev 2: 119-125.

61. Matarese G, Sanna V, Fontana S, Zappacosta S, 2002 Leptin as a Novel Therapeutic Target for Immune Intervention. Curr Drug Targets Inflamm Allergy 1: 13-22.

62. Matarese G, Moschos S, Mantzoros CS, 2005 Leptin in immunology. J Immunol 174: 3137-3142.

63. Gertler A, 2006 Development of leptin antagonists and their potential use in experimental biology and medicine. Trends Endocrinol Metab 17: 372-378.

64. Verploegen S, Plaetinck G, Devos R, van der Heyden J, Guisez Y, 1997 A human leptin mutant induces weight gain in normal mice. FEBS Lett 405: 237-240.

65. Peelman F, Van Beneden K, Zabeau L, et al, 2004 Mapping of the leptin binding sites and design of a leptin antagonist. J Biol Chem 279: 41038-41046.

66. de Barsy T, Directeur W. Geneeskundige Stichting Koningin Elisabeth 2006 Inleiding Verslag Activiteiten van de GSKE-FMRE.

67. Steidler L, Hans W, Schotte L, et al, 2000 Treatment of murine colitis by Lactococcus lactis secreting interleukin-10. Science 289: 1352.

68. Steidler L, Neirynck S, Huyghebaert N, et al, 2003 Bio- logical containment of genetically modified Lactococcus lactis for intestinal delivery of human interleukin 10 . Nat Biotechnol 21: 785-789.

69. Lam QLK, Lu L, 2007 Role of leptin in immunity. Cell Mol Immunol 4: 1-13.

70. Wu ZD, Bidlingmaier M, Liu CL, et al, 2002 Quantification of the soluble leptin receptor in human blood by ligand-mediated immunofunctional assay. J Clin Endocrinol Metab 87: 2931-2939.

71. Laimer M, Ebenbichler CF, Kaser S, et al, 2002 Weight loss increases soluble leptin receptor levels and the soluble receptor bound fraction of leptin. Obes Res 10: 597-601.

72. Huang L, Wang ZW, Li C, 2001 Modulation of circulating leptin levels by its soluble receptor. J Biol Chem 276: 6343-6349.

73. van Dielen FM, van't Veer C, Buurman WA, Greve JWM, 2002 Leptin and soluble leptin receptor levels in obese and weight-losing individuals. J Clin Endocrinol Metab 87: 1708-1716.

74. Fazeli M, Zarkesh-Esfahani H, Wu ZD, et al, 2006 Identification of a monoclonal antibody against the leptin receptor that acts as an antagonist and blocks human monocyte and $\mathrm{T}$ cell activation. $\mathrm{J}$ Immunol Methods 312: 190-200.

75. Wannamethee SG, Tchernova J, Whincup P, et al, 2007 Plasma leptin: Associations with metabolic, inflammatory and haemostatic risk factors for cardiovascular disease. Atherosclerosis 191: 418-426.

76. Elinav E, Abd-Elnabi A, Pappo O, et al, 2006 Suppression of hepatocellular carcinoma growth in mice via leptin, is associated with inhibition of tumor cell growth and natural killer cell activation. J Hepatol 44: 529-536.

77. De Rosa V, Procaccini C, Cali G, et al, 2007 A key role of leptin in the control of regulatory $\mathrm{T}$ cell proliferation. Immunity 26: 241-255.

78. Goldberg AC, Eliaschewitz FG, Montor WR, et al, 2005 Exogenous leptin restores in vitro $\mathrm{T}$ cell proliferation and cytokine synthesis in patients with Common Variable Immunodeficiency Syndrome. Clin Immunol 114: 147-153.

79. Stofkova A, Skurlova M, Tybitanclova K, Veselsky L, Zelezna B, Jurcovicova J, 2006 Relationship among nitric oxide, leptin, ACTH, corticosterone, and IL-1 beta, in the early and late phases of adjuvant arthritis in male Long Evans rats. Life Sci 79: 2486-2491.

80. Singh P, Hoffmann M, Wolk R, Shamsuzzaman ASM, Somers VK, 2007 Leptin induces C-reactive protein expression in vascular endothelial cells. Arterioscler Thromb Vasc Biol 27: E302-E307.

81. Lafrance V, Inoue W, Kan B, Luheshi GN, 2009 Leptin modulates cell morphology and cytokine release in microglia. Brain, Behavior, and Immunity. Brain Behav Immun 24: 358-365.

82. Park MC, Chung SJ, Park YB, Lee SK, 2009 Pro-inflammatory effect of leptin on peripheral blood mononuclear 
cells of patients with ankylosing spondylitis. Joint Bone Spine 76: 170-175.

83. Angelucci F, Mirabella M, Caggiula M, et al, 2005 Evidence of involvement of leptin and IL-6 peptides in the action of interferon-beta in secondary progressive multiple sclerosis. Peptides 26: 2289-2293.

84. Milewski L, Barcz E, Dziunycz P, et al, 2008 Association of leptin with inflammatory cytokines and lymphocyte subpopulations in peritoneal fluid of patients with endometriosis. J Reprod Immunol 79: 111-117.

85. Frisullo G, Mirabella M, Angelucci F, et al, 2007 The effect of disease activity on leptin, leptin receptor and suppressor of cytokine signalling-3 expression in relapsing-remitting multiple sclerosis. J Neuroimmunol 192: 174-183.

86. Sanna V, Di Giacomo A, La Cava A, et al, 2003 Leptin surge precedes onset of autoimmune encephalomyelitis and correlates with development of pathogenic $\mathrm{T}$ cell responses. J Clin Invest 111: 241-250.

87. Matarese G, Carrieri PB, La Cava A, et al, 2005 Leptin increase in multiple sclerosis associates with reduced number of CD4(+)CD25(+) regulatory T cells. Proc Natl Acad Sci USA 102: 5150-5155. 